\title{
Characterization and Wear Properties of Al 7075/Sic/Gr Hybrid Composites
}

\author{
Atla Sridhar, K.Prasanna Lakshmi
}

\begin{abstract}
In this work, dry sliding wear properties of Al $7075 \mathrm{Al}$ 7075+ 5 wt.\% SiC, Al7075 + 5 wt.\% SiC $+X$ wt.\% graphite $(X=5-10)$ hybrid nano-composites were developed by the principle of powdered metallurgy $(P / M)$. Al 7075 hybrid nano-composites are highly promising materials that would be desirable for a wide range of applications. Under dry sliding conditions, the tests were carried out on a pin-on-disk machine was used to assess the loss of wear on base metal, composite and hybrid composites were calculated by different normal loads (5-20 N), and sliding speeds $(0.5-2 \mathrm{~m} / \mathrm{s})$ and sliding distances (500-2000 m). Micro-structural examination of base metal and composites were investigated using an Optical Microscope (OM) and scanning electron microscope (SEM). The hybrid nano-composites revealed those greatest improvements in tribological results with 5 wt. \% Silicon Carbide and 10 wt. $\%$ Graphite. Main wearing mechanism for hybrid composite materials has been established to form lubricating layer on both the surface and specimen. From experimental outcomes, it has been found that wear resistance tends to increase as weight percentage of the reinforcement increases.
\end{abstract}

Keywords: Aluminum 7075, Silicon Carbide, Graphite, Wear loss, Coefficient of friction and Dry sliding behavior.

\section{INTRODUCTION}

Metal Matrix Composites (MMCs) had also expressed great the great deal of interest in the practical applications of piston liners, brakes, cam shafts as well as the aeronautical and industrial automation sectors due to their heavier weight and thermal resistance proportions. [1]. Currently, aluminum metal matrix composites (AMMCs) has been well recognized and strengthened gradually due to their engineering design characteristics, such as upgraded wear properties, lower density, particular strength and rigidity[2 ]. The advanced wear performance of AMMCs has drawn special attention in the area of tribology among so many superior properties. Use of single reinforcements in an aluminum matrix, however, can often compromise certain principles of its physical characteristics [3][4].

Revised Manuscript Received on December 30, 2019.

* Correspondence Author

Atla Sridhar*, Research Scholar, Department of Mechanical Engineering, JNTU Hyderabad, India. Email:atla.sridhar9@gmail.com

K.Prasanna Lakshmi, Associate Professor, Department of Mechanical Engineering , JNTUH CE Manthani, India. Email: prasannakaujala@gmail.com

(C) The Authors. Published by Blue Eyes Intelligence Engineering and Sciences Publication (BEIESP). This is an open access article under the CC-BY-NC-ND license http://creativecommons.org/licenses/by-nc-nd/4.0/
With the addition of SiC particles to that of the aluminum matrix alloy, both the mechanical and wear properties of composites are increased. The resulting increase in hardness, however, makes machining difficult [3]. It is therefore important to find ways of maintaining SiC's beneficial effect while at the same time overcoming the difficulties of machining SiC-reinforced composites[5]. Graphite particles have been well suited for all this purpose and their use increases the machinability and wear resistant of composites from $\mathrm{Al}-\mathrm{SiC}$. $\mathrm{Al}-\mathrm{SiC}$ composites are known as $\mathrm{Al}-\mathrm{SiC}-$ Gr hybrid composites, reinforced with graphite particles [7]. The effect of sliding speed on dry sliding wear behavior and hybrid metal matrix composites surface deformity by liquid metallurgy method was examined[8]. In the present study is aimed at investigating the tribological performance of sintered $\mathrm{Al}$ - SiC - Gr hybrid composites in this context.

\section{EXPERIMENTATION}

\section{A. Material}

This work undertaken is preparation of Aluminium/SiC/Graphite hybrid metal matrix composites using powder metallurgy technique.

- Matrix : Aluminium7075

- Reinforcement : $\mathrm{SiC}$ (primary),

$$
\text { : Graphite (secondary) }
$$

- Manufacturing method : Powder Metallurgy

Aluminium7075 powder was procured from PRABHU COPPER LTD, Mumbai. The quantity procured was $2000 \mathrm{~g}$ and in addition, $1000 \mathrm{~g}$ of Silicon Carbide, $500 \mathrm{~g}$ of Graphite was also procured. We are provided with a certificate of purity by them. So, it didn't require further testing. The particle size of Aluminium7075, Silicon Carbide and Graphite is 108 mesh (40 microns) each.

\section{B. Manufacturing Method}

In general, till today there are many manufacturing methods in practice for manufacturing of green samples. Every method has its own advantages and problems. Among the available manufacturing methods, we adopt powder metallurgy technique for manufacturing of metal matrix composites i.e., Aluminium/SiC/Graphite hybrid metal matrix composites, filling of metal powders is easily possible with this technique.

\section{Preparation of powders}

Process involved in powder metallurgy technique, 


\section{Characterization and Wear Properties of Al 7075/Sic/Gr Hybrid Composites}

starts with mixing of powder after taking required proportions of metal powders, then compacting them by applying pressure and then green specimens are sintered for gaining properties. Before initiating the process, the powders are preheated in order to remove the unwanted moisture. They are subjected to about 110-250 degree Celsius.

\section{Powders Mixing}

Weighing and mixing of powders is done according to the pre-designed spatial distribution as dictated by the functional requirement. Weighing of powders is done using electronic weighing balance. Various compositions of aluminum and silicon carbide mixtures were prepared according to fraction of weight; the sample weight was approximately 30 grams. Compositions of each and every sample were measured and were milled in ball milling to achieve homogeneous composition. From various methods available for mixing of powders, we choose ball milling and the specifications of ball mill are as follows:

Ball material $=$ Tungsten

Speed of rotation $=300 \mathrm{rpm}$

Ball to powder proportion $=10: 1$

Diameter of ball $=10 \mathrm{~mm}$

Time taken $=60$ hours

\section{E. Die Filling and Compaction} ensuring proper filling. Manual ramming was done after filling of each layer into die using punch. All layers are filled similarly into the die.

Compacting of powder filled die was done using universal testing machine on application of optimum load. Load applied also plays major role in gaining strength to the compacting specimen, in order to achieve sustainable strength, optimum load as to be known and applied. The optimum load was found to be around $140 \mathrm{KN}$ to $160 \mathrm{KN}$ after several attempts or trials from $8 \mathrm{KN}$ to $178 \mathrm{KN}$. At the end of the process, green samples are obtained.

\section{F. Sintering}

The manufactured specimens so prepared are not so strong enough, in order to achieve strength, these green samples are sintered around $80 \%$ to $95 \%$ of the melting point of Aluminium7075. After the scrutiny of literature review and several attempts of sintering process, the optimum sintering temperature and holding time adopted for this process is around 580 - 600 degree Celsius and 2-2.5 hours respectively for each specimen.

\section{G. Characterization}

After sintering process, the specimens obtained are strong enough for further process of surface finish. The obtained specimens are then undergone finishing process by the use of emery paper of 3 different grades ensuring that no large amount of material is removed from the specimen.

These samples are now used for performing different mechanical tests like hardness test, toughness test microstructure and the density of the sample specimens is calculated.
These mixtures were then filled into die layer by layer

\section{H. Microstructure}

Microstructure is the small scale structure of a material, defined as the structure of a prepared surface of material as revealed by a microscope magnification. The microstructure of a material can strongly influence properties such as hardness, toughness, strength, ductility, etc. A microstructure's influence on the mechanical and physical properties of a material is primarily governed by the different defects present or absent of the structure. These defects can take many forms but the primary ones are the pores.

\section{Wear Test}

Dry sliding wear trials for pin-on-disk instrument (DUCOM-TR-20LE-PHM 400-CHM 600, Bangalore, India) are operated as per test standards of ASTM: G99-05 [3].The counter-disk component is made of EN31 steel was used. Before inspection, specimen and disc's surface was cleaned with toluene. The total experimentation were carried out on specimen with different combinations with normal loads 5-20 N. The variable sliding range of 500-25000 m with sliding velocities of $0.5-2 \mathrm{~m} / \mathrm{s}$ were used The weight losses are measured using a precise balance of $0.001 \mathrm{~g}$ accuracy from the weight changes of specimens calculated before and after the wear analysis.

Table1. Significance of various parameters'

\begin{tabular}{|l|c|c|c|c|}
\hline $\begin{array}{l}\text { A: } \\
\text { Reinforcement }\end{array}$ & $\begin{array}{c}\mathrm{Al} \\
7075\end{array}$ & $\begin{array}{c}\mathrm{Al} 7075-5 \% \\
\mathrm{SiC}\end{array}$ & $\begin{array}{c}\mathrm{Al} \\
7075-5 \% \\
\mathrm{Sic}-5 \% \mathrm{Gr}\end{array}$ & $\begin{array}{c}\mathrm{Al} 7075-5 \% \\
\mathrm{SiC}-10 \% \\
\mathrm{Gr}\end{array}$ \\
\hline B: load & $5 \mathrm{~N}$ & $10 \mathrm{~N}$ & $15 \mathrm{~N}$ & $20 \mathrm{~N}$ \\
\hline $\begin{array}{l}\text { C:sliding } \\
\text { Distance }\end{array}$ & $500 \mathrm{~m}$ & $1000 \mathrm{~m}$ & $1500 \mathrm{~m}$ & $2000 \mathrm{~m}$ \\
\hline $\begin{array}{l}\text { D:sliding } \\
\text { Velocity }\end{array}$ & $0.5 \mathrm{~m} / \mathrm{s}$ & $1 \mathrm{~m} / \mathrm{s}$ & $1.5 \mathrm{~m} / \mathrm{s}$ & $2 \mathrm{~m} / \mathrm{s}$ \\
\hline
\end{tabular}

\section{RESULTS AND DISCUSSION}

\section{A. Density and harness}

Table 2. Mechanical Characterization (Density, Rockwell Hardness

\begin{tabular}{|r|l|l|c|}
\hline s.no. & \multicolumn{1}{|c|}{ compositions } & $\begin{array}{c}\text { Density } \\
\text { (g/cc) }\end{array}$ & $\begin{array}{c}\text { Rockwell } \\
\text { hardness number } \\
\text { (RHB) }\end{array}$ \\
\hline 1 & $\mathrm{Al} 7075$ & 2.829 & 81 \\
\hline 2 & $\mathrm{Al} 7075-5 \% \mathrm{SiC}$ & 2.841 & 86 \\
\hline 3 & $\mathrm{Al} \mathrm{7075-5 \%} \mathrm{SiC-5 \%} \mathrm{Gr}$ & 2.853 & 77 \\
\hline 4 & $\mathrm{Al} 7075-5 \% \mathrm{SiC}-10 \% \mathrm{Gr}$ & 2.865 & 72 \\
\hline
\end{tabular}

As graphite percentage increases the density and hardness values are decreasing.

\section{B. Microstructure}

For evaluate the micro-structural characterization, the produced hybrid composites are examined by the electron microscope. From sintered specimens, a section was cut being first grinded belt followed by polishing with different grades such as emery paper grades 600, 800, 1000 and 1200. 
The glossy specimens were again lapped for approximately 30 minutes on a disc polishing system using diamond-lapping paste and velvet tissue to obtain the mirror finish on the samples. The samples were etched for about 45 seconds with $5 \% \mathrm{NaOH}$ solution and washed before the microstructure analysis with distilled water. After etching they were examined at different magnifications through optical micro scope. The micro structural analysis reveals the uniform distribution of SiC particles in every specimen, the same we can observe in SEM and Optical scope images in fig (1- 4 and 7-10). And worn surface dominations and tribo layers we can clearly observe in micro scope images from fig. (11-14).

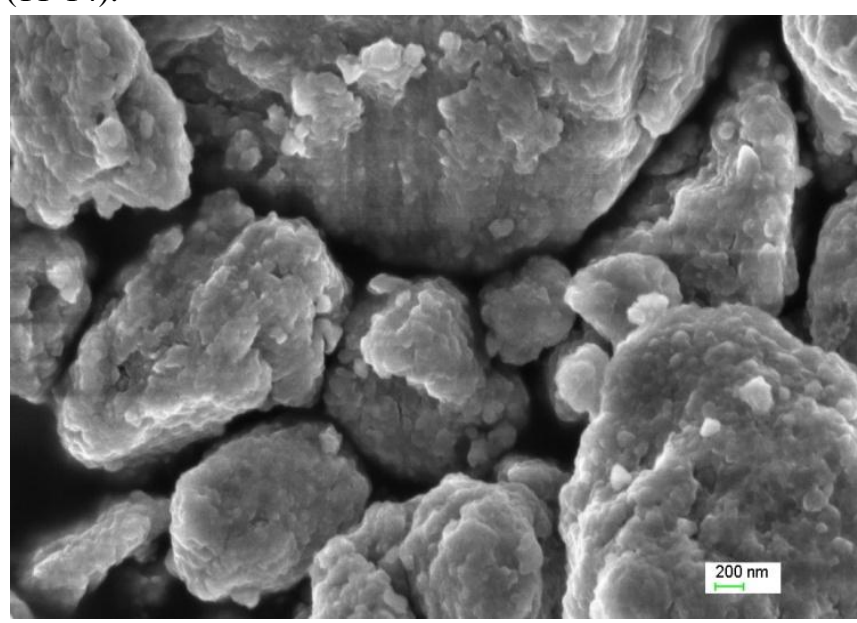

Fig. 1 Al 7075 powder after ball milling

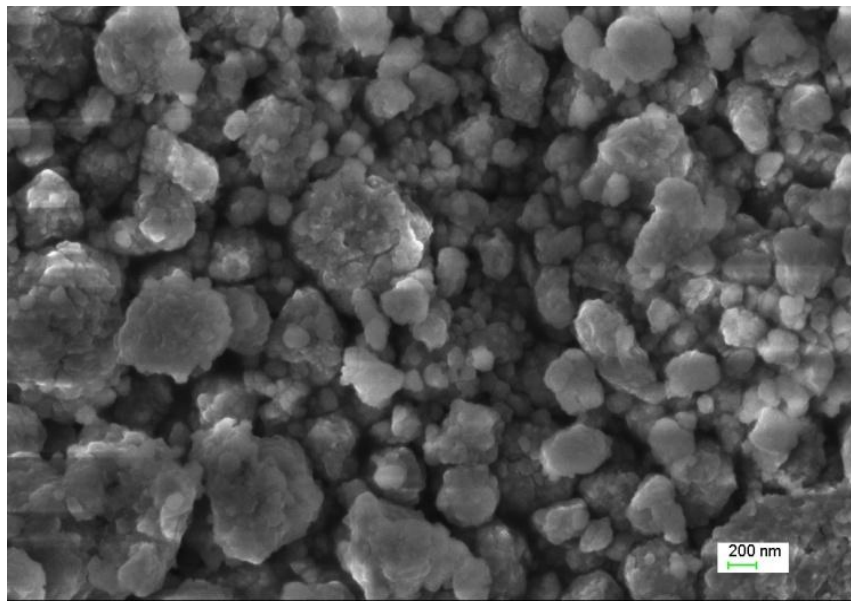

Fig. 2 Al 7075-5\% SiC powder after ball milling

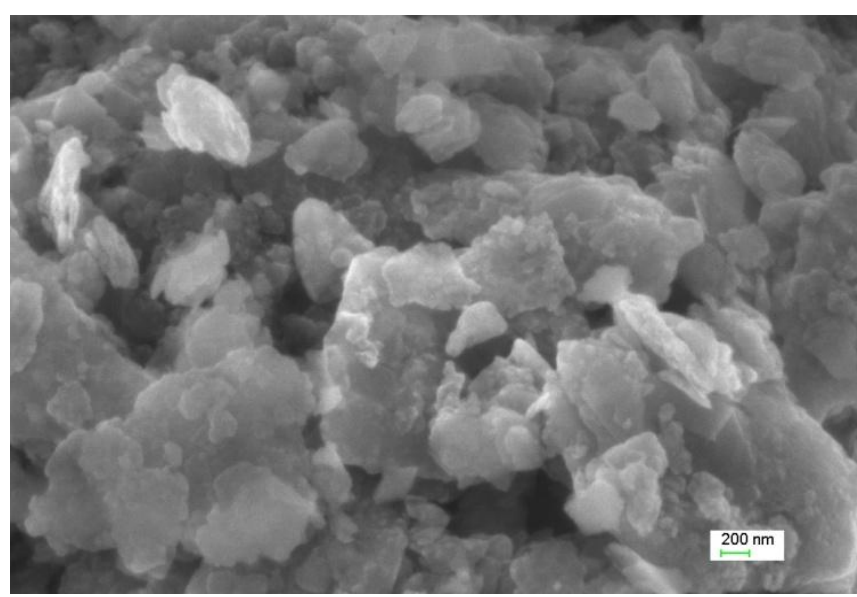

Fig.3 Al 7075-5\% SiC-5\% Gr powder after ball milling

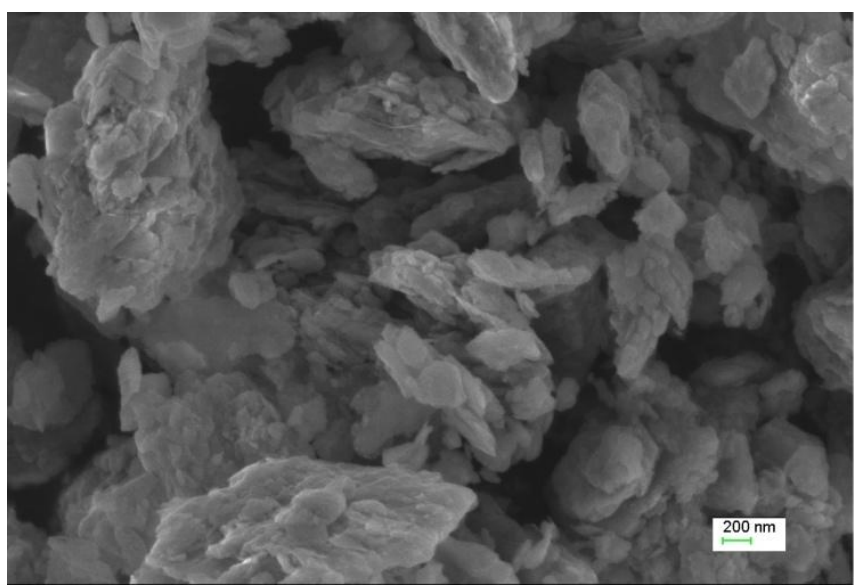

Fig.4 Al 7075-5\% SiC-10\% Gr powder after ball milling

\section{Dry sliding wear}

By using design of experiments taguchi $\mathrm{L}_{16}$ orthogonal array experimentation designed and tabulated the vales of wear loss and coefficient of friction in table3.

Table3. Experimentation (Taguchi $\mathrm{L}_{16} \mathrm{OA}$ ) with $\mathrm{S} / \mathrm{N}$ values

\begin{tabular}{|l|l|l|l|l|l|l|l|}
\hline A & $\mathbf{B}$ & $\mathbf{C}$ & $\mathbf{D}$ & $\begin{array}{l}\text { Wear } \\
\text { loss } \\
\text { (g) }\end{array}$ & $\begin{array}{c}\text { S/N ratio } \\
\text { Wear } \\
\text { loss }\end{array}$ & COF & $\begin{array}{c}\text { S/N ratio } \\
\text { Coefficient } \\
\text { of friction }\end{array}$ \\
\hline 1 & 5 & 500 & 0.5 & 0.02450 & 32.21668 & 0.2540 & 11.9033 \\
\hline 1 & 10 & 1000 & 1.0 & 0.02733 & 30.37115 & 0.2925 & 10.6775 \\
\hline 1 & 15 & 1500 & 1.5 & 0.02915 & 29.01993 & 0.2856 & 10.8848 \\
\hline 1 & 20 & 2000 & 2.0 & 0.03220 & 28.58914 & 0.3480 & 9.1684 \\
\hline 2 & 5 & 1000 & 1.5 & 0.01062 & 39.47751 & 0.1278 & 17.8694 \\
\hline 2 & 10 & 500 & 2.0 & 0.02959 & 30.5771 & 0.1258 & 18.0064 \\
\hline 2 & 15 & 2000 & 0.5 & 0.01849 & 34.66126 & 0.1458 & 16.7248 \\
\hline 2 & 20 & 1500 & 1.0 & 0.02089 & 33.60123 & 0.1778 & 15.0014 \\
\hline 3 & 5 & 1500 & 2.0 & 0.01030 & 39.74326 & 0.1458 & 16.7248 \\
\hline 3 & 10 & 2000 & 1.5 & 0.01099 & 39.18005 & 0.1118 & 19.0312 \\
\hline 3 & 15 & 500 & 1.0 & 0.01599 & 35.92303 & 0.1388 & 17.1522 \\
\hline 3 & 20 & 1000 & 0.5 & 0.01899 & 34.4295 & 0.1728 & 15.2491 \\
\hline 4 & 5 & 2000 & 1.0 & 0.01322 & 37.57537 & 0.1508 & 16.4320 \\
\hline 4 & 10 & 1500 & 0.5 & 0.01680 & 35.49381 & 0.1448 & 16.7846 \\
\hline 4 & 15 & 1000 & 2.0 & 0.02088 & 33.60539 & 0.1758 & 15.0996 \\
\hline 4 & 20 & 500 & 1.5 & 0.02340 & 32.61568 & 0.1848 & 14.6660 \\
\hline
\end{tabular}

From the obtained experimental data, calculated S/N ratio values through Mini tab 19.0 software for wear loss and coefficient of friction values are recorded in table.3. After that analysis of variance was done through ANNOVA, and the analyzed data, percentage of contribution is also can be observed in table 4 and table.5. Response tables are also drawn and are noted in table6 and table7.

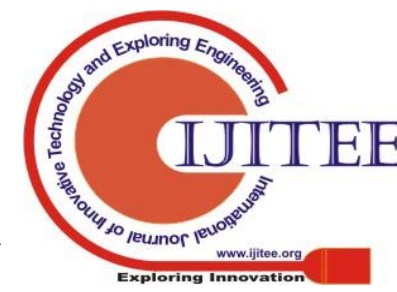




\section{Characterization and Wear Properties of Al 7075/Sic/Gr Hybrid Composites}

Table.4 Analysis of Variance for $\mathrm{S} / \mathrm{N}$ ratios for wear loss

\begin{tabular}{|c|c|c|c|c|c|c|}
\hline Source & DF & $\begin{array}{l}\text { Seq } \\
\text { SS }\end{array}$ & $\begin{array}{l}\text { Adj } \\
\text { MS }\end{array}$ & $\mathbf{F}$ & $\mathbf{P}$ & $\begin{array}{c}\% \text { of } \\
\text { contribution } \\
\end{array}$ \\
\hline reinforcement(sample) & 3 & 63.106 & 21.0354 & 40.37 & 0.006 & 44.34 \\
\hline load & 3 & 74.524 & 24.8413 & 47.68 & 0.005 & 52.37 \\
\hline sliding distance & 3 & 2.918 & 0.9726 & 1.87 & 0.311 & 2.05 \\
\hline sliding velocity & 3 & 0.201 & 0.0670 & 0.13 & 0.937 & 0.14 \\
\hline Residual Error & 3 & 1.563 & 0.5210 & & & 1.09 \\
\hline Total & & 142.312 & & & & \\
\hline \multicolumn{7}{|c|}{$\mathrm{R}-\mathrm{Sq}=98,90 \%, \mathrm{R}-\mathrm{Sq}(\mathrm{adj})=94.51 \%$} \\
\hline \multicolumn{7}{|c|}{$\begin{array}{c}\text { Table. } 5 \text { Analysis of Variance for } \mathrm{S} / \mathrm{N} \text { ratios for } \\
\text { coefficient of friction }\end{array}$} \\
\hline Source & DF & $\begin{array}{l}\text { Seq } \\
\text { SS }\end{array}$ & $\begin{array}{l}\text { Adj } \\
\text { MS }\end{array}$ & $\mathbf{F}$ & $\mathbf{P}$ & $\begin{array}{c}\text { \% of } \\
\text { contribution }\end{array}$ \\
\hline reinforcement(sample) & 3 & 108.582 & 36.1941 & 130.31 & 0.001 & 84.41 \\
\hline load & 3 & 15.841 & 5.2803 & 19.01 & 0.019 & 12.31 \\
\hline sliding distance & 3 & 1.484 & 0.4948 & 1.78 & 0.324 & 1.15 \\
\hline sliding velocity & 3 & 1.880 & 0.6266 & 2.26 & 0.261 & 1.46 \\
\hline Residual Error & 3 & 0.833 & 0.2778 & & & 0.64 \\
\hline Total & 15 & 128.620 & & & & \\
\hline
\end{tabular}

$\mathrm{R}-\mathrm{Sq}=99.48 \%, \mathrm{R}-\mathrm{Sq}(\mathrm{adj})=97.391 \%$

Table.6 Response Table for Signal to Noise Ratios for wear loss

Smaller is better

\begin{tabular}{rccrr} 
Level & reinforcement(sample) & load & $\begin{array}{r}\text { sliding } \\
\text { distance }\end{array}$ & $\begin{array}{r}\text { sliding } \\
\text { velocity }\end{array}$ \\
\hline 1 & 30.11 & 35.99 & 31.91 & 32.49 \\
2 & 31.43 & 32.54 & 32.26 & 32.60 \\
3 & 32.94 & 30.75 & 32.71 & 32.54 \\
4 & 35.45 & 30.65 & 33.04 & 32.30 \\
Delta & 5.34 & 5.34 & 1.12 & 0.30 \\
Rank & 2 & 1 & 3 & 4
\end{tabular}

Table.7 Response Table for Signal to Noise Ratios for coefficient of friction

Smaller is better

\begin{tabular}{rcrrr} 
Level & reinforcement(sample) & $\begin{array}{c}\text { loa } \\
\text { d }\end{array}$ & $\begin{array}{c}\text { sliding } \\
\text { distance }\end{array}$ & $\begin{array}{c}\text { sliding } \\
\text { velocity }\end{array}$ \\
\hline 1 & 10.66 & 15.73 & 15.43 & 15.17 \\
2 & 16.90 & 16.12 & 14.72 & 14.82 \\
3 & 17.04 & 14.97 & 14.85 & 15.61 \\
4 & 15.75 & 13.52 & 15.34 & 14.75 \\
Delta & 6.38 & 2.60 & 0.71 & 0.86 \\
Rank & 1 & 2 & 4 & 3 \\
\hline
\end{tabular}

Fig.5 Wear loss Vs parameters

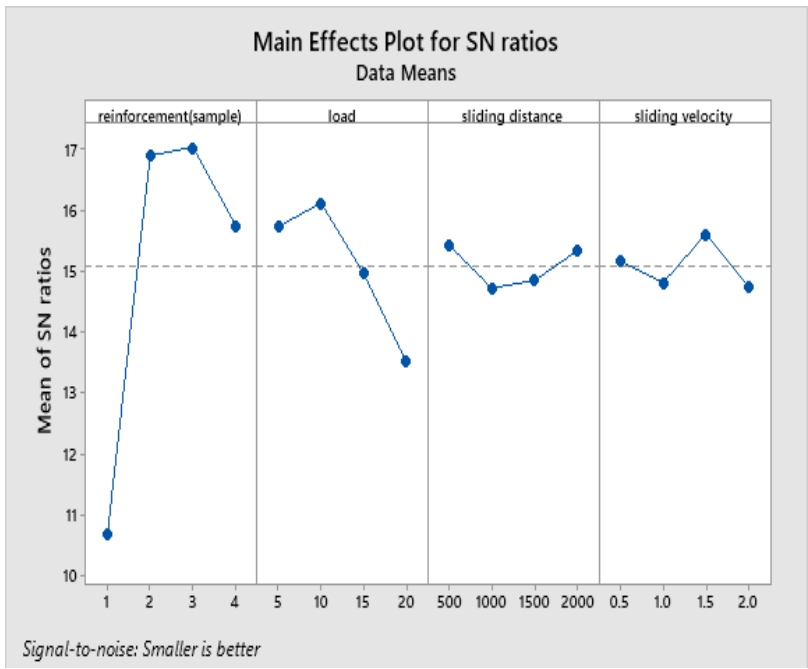

Fig. 6 COF Vs parameters

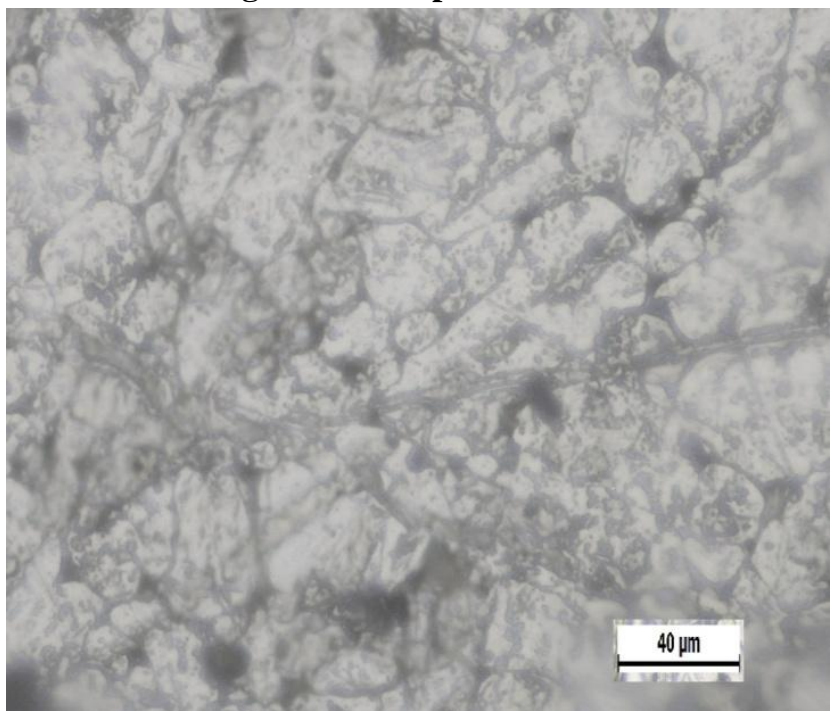

Fig. 7 Al 7075 micro structure after sintering 


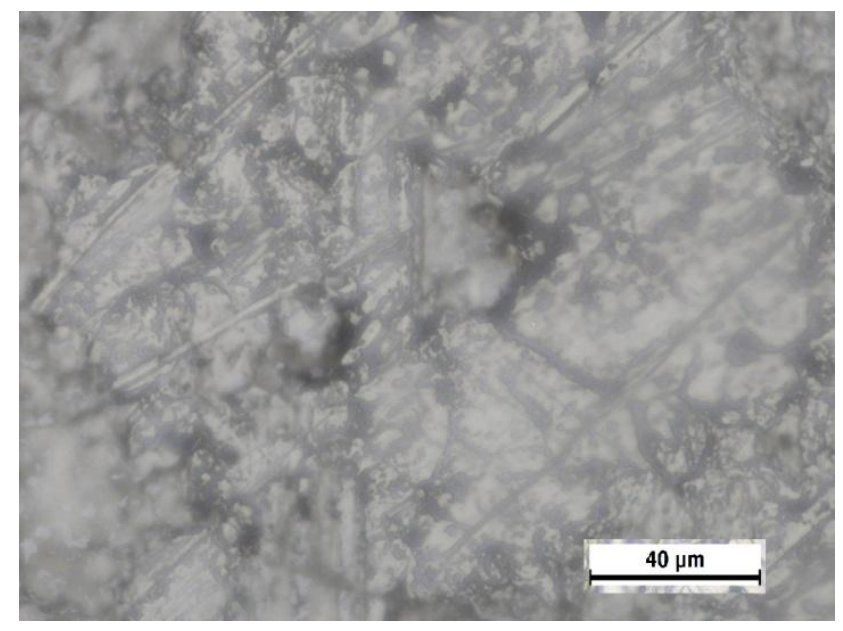

Fig. 8 Al 7075-5\% SiC micro structure after sintering

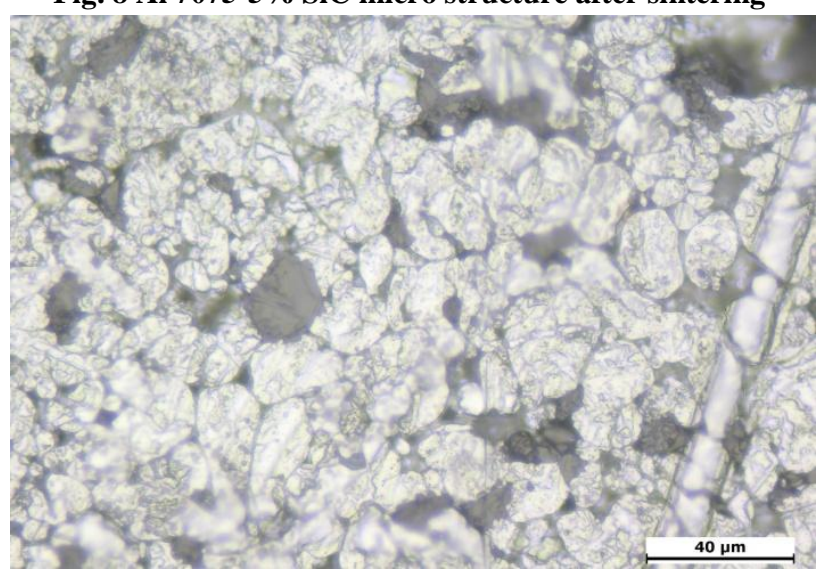

Fig.9 Al 7075-5\%SiC- 5\% Gr micro structure after sintering

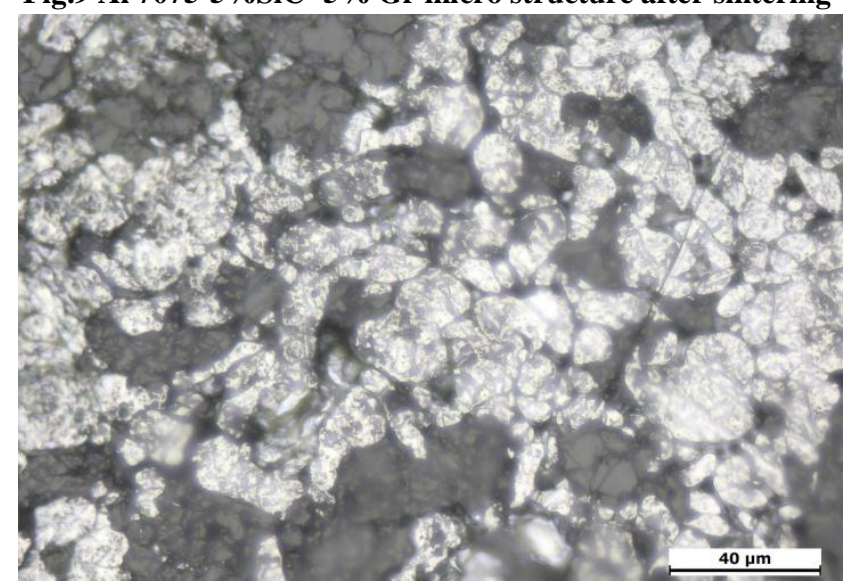

Fig.10 Al 7075-5\%SiC-10\% Gr micro structure after sintering

\section{Significance of parameters on wear loss}

The major affects of the effect of a different test constraints on both loss of wear and also the composite frictional coefficient. Whether the lines for a given parameters is closer to horizontal in main effects graph, thus the parameter will have no significant impact. In comparison, a most significant effect is a parameter whereby the line has the greatest tendency. From major effects graph, this was evident that variable B (load) is the most significant factor, whereas variables $\mathrm{C}$ (sliding distance), A (percentage of reinforcement) and D (sliding velocity) had comparatively less significance. Loss of wear increased as when the load applied and the sliding distance increased, indicating more material removal from the surface. Furthermore, wear-loss significantly reduced due to the forming of something like a graphite rich thin coated surface on wear out surfaces with an increase in sliding speed, thereby minimizing wear by exposing more contact area. Particularly in comparison to all other combinations (i.e. 0 percent graphite and 10 percent graphite) the composite with 5 percent had shown better wear resistance at higher loads.

\section{E. Significance of parameters on coefficient of friction}

From the obtained graphs the test parameters are significantly effecting coefficient of friction. The normal load applied was perhaps the most main factor affecting the composite's friction coefficient because variable $\mathrm{B}$ has the greatest tendency, whereas the percentage of reinforcement and sliding velocity had only minor effects. But the friction managed to remain literally deterministic to all composite materials with that of the sliding distance. The rise in a the load applied massively improved the composite friction coefficient since the graphite film is noticed to have been more robust at smaller load than at higher loads as the film is lost at a fast rate with load increases. It is due to fact that the aluminum matrix is reinforced with graphite that also serves as solid lubricants on a surfaces and develops a solid lubricant rich layer on tribosurface which reduces frictional resistance by avoiding metal-to-metal interaction at a sliding layer. Whenever the weight percentage of graphite increases above $5 \%$ then the friction also increases because that the oxidized layer cracks within the surface and that erodes scratched surface.

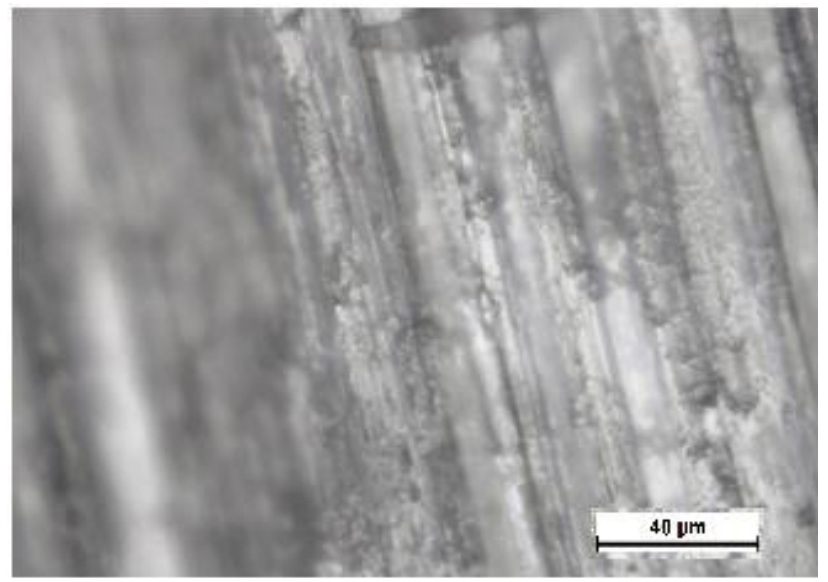

Fig. 11 Al 7075

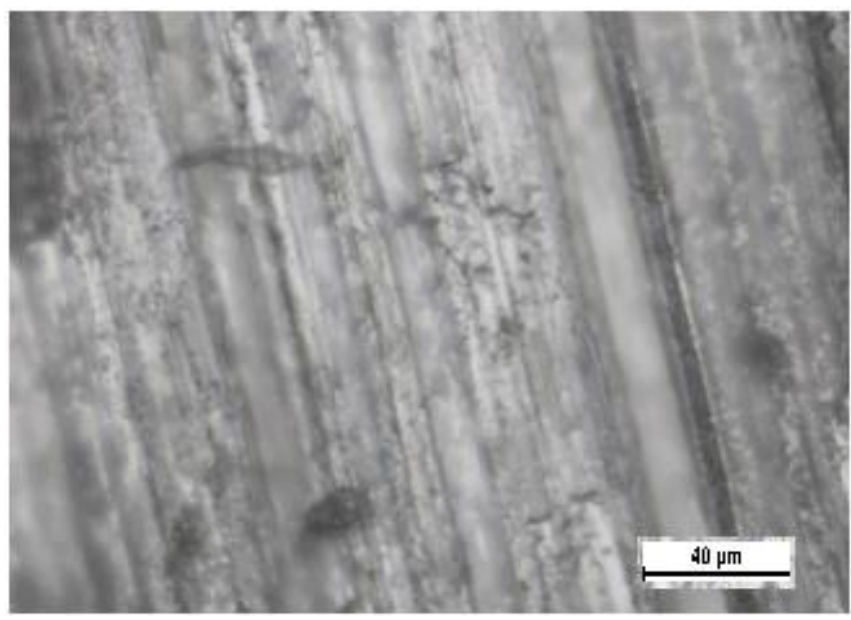

Fig. 12 Al 7075- 5\% SiC

Published By:

Blue Eyes Intelligence Engineering

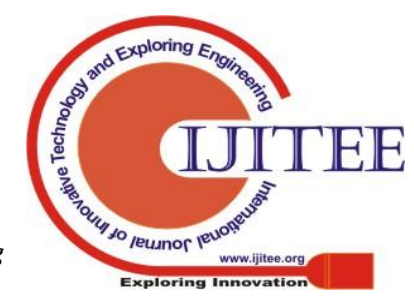




\section{Characterization and Wear Properties of Al 7075/Sic/Gr Hybrid Composites}

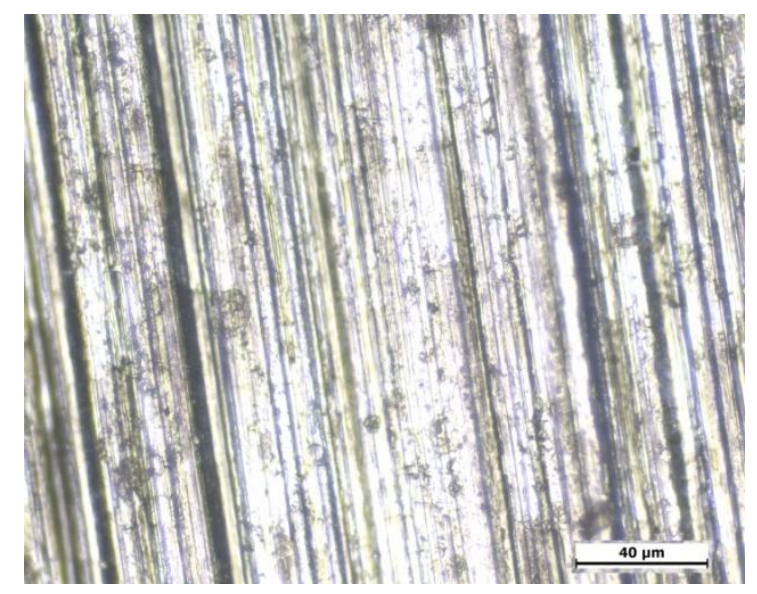

Fig. 13 Al 7075- 5\%SiC - 5 \%Gr

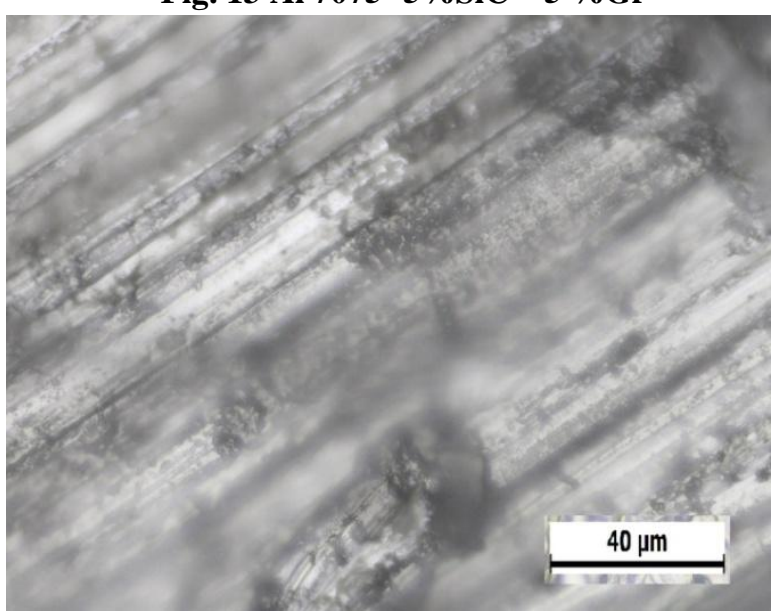

Fig. 14 Al 7075- 5\% SiC - $10 \%$ Gr

F. Analyzing and evaluating the results of the experiments using the Taguchi method

Signal / Noise Ratio (S / N) is really the important benchmark for Taguchi technique to analyze experimentation data. In this research, as per Taguchi rule, the $\mathrm{S} / \mathrm{N}$ value must have a highest value under optimal testing condition. The loss of wear and frictional coefficient $\mathrm{S}$ / $\mathrm{N}$ ratio values for the processed composite materials are noted in table. The tabulated values showing the mean of a chosen design elements for every factor point. Its response table incorporates rankings based on Delta statistical analysis. The Delta characteristics were allocated to rankings; the maximum Delta valuation is allocated to 1st rank, that second largest Delta valuation to 2nd rank and so forth. Optimum parameters are: $5 \%$ gr reinforcing material, normal load of 5 N, 1500 m slides and 2 m / s sliding velocity for optimum wear resistance and 5\% gr reinforcing material, $15 \mathrm{~N}$ load $500 \mathrm{~m}$ sliding length and $1 \mathrm{~m} / \mathrm{s}$ slide velocity for the better friction performance.

\section{CONCLUSION}

Development of hybrid nano composites of homogeneous distribution of reinforcing particulates through the method of powder metallurgy were validated with Scanning electron microscope (SEM) and optical microscope morphological images and wear findings. As the percentage of graphite in hybrid composites increases, the density and hardness values decrease. The wear losses of the composites improves as addition of graphite improves until 5 percent $\mathrm{Gr}$, then decreases to a lesser value of 10 percent Gr. Hybrid nano composite material's wear resistance were better than that of the base metal. Worn surfaces analysis indicated that wear was delaminated including some oxidation wear mechanism by an influential wear mechanism for unreinforced Al 7075 base metal. However, worn surface layers of the hybrids were softer and also the deforming depth was lower than that of unreinforced aluminum 7075 base alloy. In addition, wore debris will decrease as addition of graphite tends to increase. The lubrication layer appears to be a major factor in regulating such hybrid nano composite's wear behaviour analysis.

This effort of using high synthetic ceramic particulates (sic) and self lubricating particulates (gr) as hybrid reinforcement will significantly optimize the tribological characteristics of nano composites, therefore introducing a new direction for the design of super lightweight materials incorporated in different industrial and engineering fields.

\section{REFERENCES}

1. Nagavelly shiva kumar 'mechanical and wear bahaviour of ZA-27/SiC/Gr hybrid metal matrx composites', material today proceedings 5 (2018) 19969-19975.

2. Rathod abhishek, umasankar v, xavior,' evaluation of properties for Al-SiC reinforced metal matrix composite for brake pads.

3. Atla Sridhar, K.Prasanna Lakshmi 'Mechanical and tribological properties of $\mathrm{Al} 7075$ /SiC/ Graphite hybrid composites processed by powder metallurgy technique' IJITEE ISSN: 2278-3075, Volume-8 Issue-11, September 2019

4. Atla Sridhar and Dr. K. Prasanna Lakshmi "Effect of silicon carbide particulates on characterization and mechanical properties of A 7075 metal matrix composites" Vol. 8 Issue 2, April -June, Issue 2019.

5. S. Mitrovic, M. babic, M.pantic, "tribological potential of hybrid composites based on Zinc and Aluminum alloys reinforced with SiC and Graphite particles. Tribology in industry vol.34, n0 4(2012) 177-185.

6. Rajesh purohit, R.S rana, C.S varma,'fabrication of Al-sic composites through powder metallurgy process and testing of properties.ijera ISSn: 2248-9622, vol-2, issue 3, may-jun 2012, pp.420-4437.

7. P. Ravindrana, n , K. Manisekar, R. Narayanasamy,, P. Narayanasamy "Tribological behaviour of powder metallurgy-processed aluminium hybrid composites with the addition of graphite solid lubricant" Ceramics International 39 (2013) 1169-1182.

8. N. Miloradovi, B. Stojanovi, "Tribological behavior of ZA27/10SiC/1Gr hybrid composite" Journal of the Balkan Tribological Association Vol. 19, No 1, 97-105 (2013).

\section{AUTHORS PROFILE}

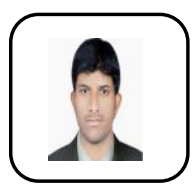

I Atla Sridhar, Research Scholar in JNTU Hyderabad, and $\mathrm{i}$ am working as a Assistant profesor in GITAM University Hyderabad. I have total 9 years of teaching experience in teaching and research. My research interest is composites, tribology and $3 \mathrm{D}$ printing

I Dr. K Prasanna Lakshmi , PhD, working as Associate Professor of Mechanical Engineering Mechanical Engineering Department, JNTU college of engineering Manthani. 15 years of teaching experience in teaching and research. My research intrest is production engineering, specially Automation in manufacturing, composites. 